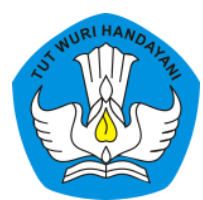

Page: 741-758

\title{
Pengembangan Media Tak Tik Butarna Berbasis STEAM pada Pembelajaran Tematik Kelas 1 SD
}

\author{
Anik Twiningsih ${ }^{1}$ \\ Sekolah Dasar Negeri Laweyan No.54 Kota Surakarta \\ ContributorEmail: anik.twin@gmail.com
}

Article Url: http:/ / ojsdikdas.kemdikbud.go.id/index.php/didaktika/article/view/143

\begin{abstract}
The purpose of this study is to develop STEAM-based learning media (Science, Technology, Engineering, Arts, Mathematics) in grade 1 thematic learning to improve critical thinking skills and culture of scientific literacy in grade 1 students. This media was developed based on the STEAM approach, so the use of media through the syntax of analyzing, synthesizing, making conclusions and organizing strategies and tactics. The excellence of this innovative work focuses on improving critical thinking skills and scientific literacy. This type of research is research and development (Research and Development) with ADDIE design (Analysis, Design, Development, Implementation, Evaluation). Based on the results of the study before using STEAM-based butik media, it is known that the average class of students' critical thinking skills is 74.80 and the average science literacy class is 73.61. After using STEAM-based typewriter media it can be seen that the average class of students' critical thinking skills is 86.67 and the average science literacy class is 88.67. The results of this study prove that STEAM-based non-typed media developed can improve students' critical thinking skills so that it has a positive impact on scientific literacy. The conclusion of this study is that new learning media developed can increase the activeness of students and ultimately have a positive impact on student learning outcomes.
\end{abstract}

Keywords: Tak Tik Butarna media; STEAM; critical thinking skills 


\begin{abstract}
Abstrak
Abstrak harus mencerminkan keseluruhan substansi isi artikel dan mampu membantu pembaca untuk menentukan relevansinya dengan minat serta memutuskan apakah akan membaca dokumen secara keseluruhan. Abstrak berisi pernyataan tentang latar belakang masalah, tujuan penelitian atau fokus masalah, metode atau tahapan penting penelitian, serta temuan dan simpulan utama. Abstrak disajikan dalam dua bahasa, yaitu bahasa Indonesia dan bahasa Inggris dengan panjang antara 150-200 kata. Abstrak ditulis dalam huruf miring, spasi 1, ukuran 10,5, dengan menggunakan Font Book Antiqua serta mencantumkan antara 3-5 kata kunci. Kata kunci berisi istilah penting dan substansi naskah. Kata kunci dapat diambil dari variabel penelitian. Kata kunci bukan berupa singkatan atau akronim kreasi penulis.
\end{abstract}

Kata Kunci: Media tak tik butarna; STEAM; Keterampilan berpikir kritis

\title{
A. Pendahuluan
}

Guru sebagai motor penggerak utama dalam pendidikan sangat menentukan out put peserta didik. Strategi guru dalam menghadapi berbagai tantangan dalam perkembangan ilmu pengetahuan saat ini diperlukan peran aktif guru dalam mengembangkan inovasi pembelajaran. Paradigma pendidikan masa kini menuntut guru senantiasa dinamis, dalam hal ini dinamis dalam menyerap segala informasi positif terutama tantangan pendidikan abad 21 yang saat ini menjadi agenda pemerintah dalam merevitalisasi segala aspek pendidikan, termasuk upaya memberdayakan keterampilan abad 21 yang diamanahkan kepada peserta didik, meliputi keterampilan 4C, keterampilam 4C yang dimaksud antara lain Critical Thinking, Comunication, Collaboration, serta Creative Thinking.

Permasalahan guru dalam kegiatan pembelajaran di kelas yang lazim adalah terbatasnya media pembelajaran yang tersedia. Media pembelajaran yang ada belum memenuhi kebutuhan peserta didik dalam sehingga berdampak pada hasil belajar peserta didik. Media yang tersedia belum sepenuhnya tepat pada tujuan pembelajaran sehingga perlu adanya kreatifitas guru dalam menciptakan inovasi media belajar agar memberikan atmosfer kelas yang kondusif. Atmosfer kelas yang kondusif memberikan 
rasa nyaman pada peserta didik dalam belajar sehingga memudahkan peserta didik dalam menerima ilmu yang disampaikan oleh guru.

Menurut Agung, M.,(2017) Pemanfaatan media belajar dalam kegiatan belajar dapat membangun ketertarikan dan perhatian peserta didik sehingga memberikan motivasi peserta didik dalam proses belajar mengajar yang pada akhirnya dapat meningkatkan pemahaman dan prestasi belajar. Rosita Primasari (2014) media pembelajaran berfungsi untuk menyajikan objek belajar peserta didik yang tidak dapat dilihat secara langsung atau terlalu kecil agar dapat dilihat dan diamati secara langsung sehingga memmudahkan peserta didik dalam belajar, misalnya dari kecil menjadi besar, menjadikan permasalahan yang rumit menjadi mudah, sistematik dan sederhana. Falahudin, I. (2014) berpendapat media belajar adalah meliputi alat atau bahan pembelajar dalam pembelajaran serta sebagai alat penyampai pesan dari media belajar kepada peserta didik. Dari beberapa pendapat diatas dapat disimpulkan bahwa media belajar adalah alat bantu dalam kegiatan belajar mengajar untuk memberikan kemudahan peserta didik dalam mempelajari konsep belajar.

Masih menurut Agung, media pembelajaran yang efektif dapat menentukan hasil belajar. Media belajar dapat menumbuhkan ketertarikan peserta didik sehingga lebih fokus dalam pembelajaran yang pada akhirnya memberikan motivasi peserta didik dan mampu meningkatkan pemahaman serta prestasi belajar (Agung, 2017). Media pembelajaran sebagai alat penyampai pesan dari media belajar kepada peserta didik berfungsi untuk menyajikan objek belajar yang menjadikan permasalahan yang rumit menjadi mudah, sistematik dan sederhana (Primasari, 2014; Falahudin, 2014).

Media belajar hasil inovasi guru memberikan pembelajaran lebih bermakna karena disusun oleh guru dengan mempertimbangkan kondisi peserta didik sehingga lebih tepat guna. Media belajar sebagai alat membantu mengirim pesan secara nyata. Dengan media belajar inovatif akan membangun keterampilan peserta didik baik keterampilan dalam berpikir maupun keterampilan dalam berliterasi. 
Keterampilan berpikir kritis erat hubungannya dengan berliterasi. Berpikir kritis peserta didik akan memberikan peningkatan pula pada keterampilan peserta didik dalam literasi. Keterampilan berpikir secara aktif dalam memecahkan masalah kehidupan nyata dengan cara menganalisis, mensintesis, sehingga dapat menyimpulkan hasil penngamatan dengan benar dan ilmiah (Irawan, 2016; Lestari, 2016). Dengan demikian, maka pengambilan keputusan yang didasarkan pada kemampuan kritis merupakan wujud dari literasi sains yang baik dengan landasan ilmu pengetahuan (Gerardini, 2016). Literasi sains sebagai pengetahuan dan kecakapan limiah untuk mampu mengidentifikasi pertanyaan, memperoleh pengetahuan baru, menjelaskan fenomena ilmiah, serta mengambil simpulan berdasarkan fakta, memahami karakteristik sains, kesadaran bagaimana sains dan technology membentuk lingkungan alam, intelektual, dan budaya, serta kemauan untuk terlibat dan peduli terhadap isu-isu yang terkait sains (OECD,2016).

Science, Technology, Engenering, Arts, Mathematic (STEAM) berhubungan dengan sains, teknologi, teknik, seni, serta matematika. Sains berhubungan dengan cara berpikir (a way of thinking) melalui kegiatan mengamati dan melakukan percobaan, teknologi merupakan cara (a way of doing) melalui kegiatan menggunakan alat, teknik dapat diartikan cara melakukan (a way of doing) yang menyangkut dengan pemecahan masalah, cara menggunakan bahan yang bervariasi, desain, serta berkreasi dengan seni, matematika berhubungan dengan cara mengukur (a way of measuring) (Imaduddin, 2017). STEAM merupakan pengembangan dari pendidikan STEM dengan menambahkan unsur seni (Arts) dalam kegiatan pembelajaran (Apriliana et al., 2018).

STEAM bertujuan menstimulasi dan motivasi peserta didik berkenaan dengan cara berpikir tingkat tinggi yang mencakup cara memecahkan masalah, strategi kerjasama, belajar mandiri, belajar berbasis proyek, belajar berbasis tantangan, dan penelitian. Pembelajaran STEM tidak hanya berarti penguatan pendidikan praktis bidang STEM secara terpisah, sehingga siswa dapat memahami serta membuat keputusan tentang kondisi alam dan perubahannya sebagai aktivitas dari manusia dalam kehidupan sehari - hari (Aldila, 2017; Permanasari, 2016). 
Media belajar inovatif dapat membangun antusiasme belajar peserta didik, dapat membangun keterampilan berpikir peserta didik yang akhirnya akan menghasilkan keterampilan berliterasi peserta didik. Keterampilan literasi peserta didik yang baik akan memberikan peningkatan pada hasil belajar peserta didik sehingga tercipta iklim pembelajaran kondusif. Berdasarkan permasalahan yang telah diuraikan, maka dipandang penting untuk mngembangkan media belajar yang berbasis STEAM. Imaduddin, M. (2017) STEAM merupakan kegiatan yang berhubungan dengan sains, teknologi, teknik, seni, dan matematika. Sains berhubungan dengan cara berpikir (a way of thinking) melalui kegiatan mengamati dan percobaan, teknologi merupakan cara (a way of doing) melalui kegiatan menggunakan alat, teknik merupakan cara melakukan (a way of doing) berhubungan dengan cara pemecahan masalah, menggunakan variasi bahan, desain,serta berkreasi dengan seni, matematika berhubungan dengan cara mengukur (a way of measuring). Mentari Reza Apriliana dkk (2018) STEAM merupakan pengembangan dari pendidikan STEM dengan menambahkan unsur seni (Artss) dalam kegiatan pembelajaran. STEAM bertujuan menstimulasi dan motivasi peserta didik berkenaan dengan cara berpikir tingkat tinggi yang mencakup cara memecahkan masalah, strategi kerjasama, belajar mandiri, belajar berbasis proyek, belajar berbasis tantangan, dan penelitian.

Aldila, C, (2017) berpendapat bahwa pembelajaran STEM tidak hanya berArtsi penguatan pendidikn praktis bidang STEM secara terpisah, tetapi untuk mengembangkan pendekatan pendidikan yang mengintegrasikan ilmu pengetahuan, Technology, teknik dan matematika, dengan berfokus pada pendidikan. Menurut Permanasari, A., (2016) literasi STEM atau literasi sains dan Technology adalah kemampuan dalam menggunakan pengetahuan sains dan penerapannya, mengidentifikasi masalah dan menarik kesimpulan berdasarkan bukti dalam rangka memahami serta membuat keputusan tentang kondisi alam dan perubahannya sebagai aktivitas dari manusia dalam kehidupan sehari - hari. 
Berdasarkan uraian tersebut, dapat diidentifikasi permasalahan sebagai berikut, 1) media pembelajaran seperti apa yang berbasis STEAM dan efektif untuk mengajarkan pembelajaran tematik 1 SD? 2) bagaimana cara mengembangkan media pembelajaran berbasis STEAM yang efektif untuk mengajarkan pembelajaran tematik 1 SD? 3) bagaimana dampak media tersebut setelah dimanfaatkan dalam pembelajaran?

Irawan A, (2016) kemampuan berpikir kritis merupakan kemampuan peserta didik dalam menganalisis dan mengevaluasi berbagai bentuk keputusan yang akan dilakukan sehingga dapat menyimpulkan hasil penngamatan secara langsung. Anggi Lestari (2016) kemampuan berpikir kritis merupakan kemampuan dalam menganalisis dan memberikan evaluasi terhadap keputusan yang akan diambil. Dari pernyatan diatas dapat disimpulkan berpikir kritis adalah keterampilan berpikir secara aktif dalam memecahkan masalah kehidupan nyata dengan cara menganalisis, mensintesis, membuat kesimpulan serta mengatur strategi atau taktik agar dapat menyelesaikan permasalahan tersebut dengan baik.

\section{Literasi Sains}

Riska Gantari (2016:24) menyatakan bahwa literasi sebagai kemampuan untuk membaca dan menulis. Kemampuan literasi juga berhubungan dengan pembiasaan dalam membaca dan mengapresiasi karya sastra. Literasi berkaitan dengan kemampuan berpikir dan belajar seumur hidup untuk bertahan hidup dalam lingkungan sosial budaya. Monalisa Gerardini (2016:254) menyatakan bahwa literasi sains berasal dari bahsa latin yaitu literatus, artinya ditandai dengan huruf, melek huruf, atau pendidikan dan scientia, yang artinya memiliki pengetahuan. Dari dua pendapat diatas dapat ditarik kesimpulan bahwa literasi sains merupakan kemampuan untuk membaca dan menulis yang berhubungan dengan pembiasaan membaca serta mengapresiasi karya sastra khususnya yang berhubungan dengan pengetahuan.

Literasi sains dapat diartikan sebagai pengetahuan dan kecakapan limiah untuk mampu mengidentifikasi pertanyaan, memperoleh pengetahuan 
baru, menjelaskan fenomena ilmiah, serta mengambil simpulan berdasarkan fakta, memahami karakteristik sains, kesadaran bagaimana sains dan technology membentuk lingkungan alam, intelektual, dan budaya, serta kemauan untuk terlibat dan peduli terhadap isu-isu yang terkait sains (OECD, 2016). Instrumen penilaian literasi Sains PISA meliputi aspek kompetensi sains, aspek pengetahuan sains, dan aspek sikap yang berhubungan dengan konteks sains (OECD, 2013).

\section{B. Metode}

Metode penelitian inovasi pembelajaran berbasis STEAM mengacu pada rancangan penelitian dan pengembangan (Research and Development) dengan mengambil desain pengembangan ADDIE (Analysis, Design, Development, Implementation, Evaluation). Menurut Mulyatiningsih Endang (2012) tahapan desain pengembangan ADDIE sebagai berikut.

Tabel 1. Tahapan Pengembangan

\begin{tabular}{|l|l|}
\hline \multicolumn{1}{|c|}{ Tahapan } & \multicolumn{1}{c|}{ Kegiatan } \\
\hline Analisis & $\begin{array}{l}\text { Analisis kebutuhan guru dan peserta didik perlunya pengembangan media } \\
\text { inovasi pembelajaran serta memilih skala prioritas masalah yang segera } \\
\text { diselesaikan. }\end{array}$ \\
\hline Design & $\begin{array}{l}\text { Menentukan pendekatan pembelajaran yang akan diterapkan, merancang } \\
\text { media inovasi, merancang instrumen penilaian }\end{array}$ \\
\hline Development & $\begin{array}{l}\text { Mengembangkan media inovasi sesuai dengan pendekatan pembelajaran } \\
\text { yang telah dipilih }\end{array}$ \\
\hline Implementation & $\begin{array}{l}\text { Mengujicobakan media inovasi, melaksanakan penilaian pembelajaran, } \\
\text { pembagian angket respon }\end{array}$ \\
\hline Evaluation & $\begin{array}{l}\text { Melakukan analisis data serta melakukan revisi atau perbaikan terhadap } \\
\text { media inovasi yang telah diterapkan }\end{array}$ \\
\hline
\end{tabular}

Subjek penelitian ini adalah peserta didik kelas 1 SD Negeri Laweyan Kota Surakarta berjumlah 25 peserta didik tahun pelajaran 2018/2019. Instrumen penelitian ini lembar validasi media, lembar angket respon guru, lembar observasi peserta didik, dan lembar hasil belajar peserta didik. Jenis data yang dihasil dari penelitian ini berupa data deskriptif kualitatif dan deskriptif kuantitatif. Teknik analisis data dari hasil penelitian ini adalah teknik analisis deskriptif, deskriptif kuantitatif dan analisis kuantitatif. Teknik analisis deskriptif kuantitatif digunakan untuk menganalisis keterlaksanaan 
implementasi media tak tik butarna berbasis STEAM. Hasil observasi peserta didik dianalisis menggunakan rumus sebagai berikut.

Skor Akhir $=\frac{\text { Jumlah perolehan skor }}{\text { Skor maksimal }} \times 100 \%$

Skormaksimal = Banyaknyaindikator

Kategori nilai hasil observasi selanjutnya dikonversikan sebagaimana pada tabel 2.

Tabel 2. Kategori Skor Observasi
\begin{tabular}{|c|c|}
\hline Skor (\%) & Kategori \\
\hline $86-100$ & Sangat Baik \\
\hline $76-85$ & Baik \\
\hline $60-75$ & Kurang \\
\hline $55-59$ & Cukup \\
\hline
\end{tabular}

\section{Hasil dan Pembahasan}

\section{Analisis Kebutuhan}

Pengembangan media pembelajaran berbasis STEAM untuk pembelajaran tematik 1 harus dirancang secara sistematis. Adapun langkah-langkah pengembangan media pembelajaran sebagai berikut:

\section{Analisis Kebutuhan}

Dalam proses pembelajaran kelas 1 SD pada tema 1, yang baru tahap pertama sekaolah di SD harus dibuat semenarik mungkin agar siswa tidak frustasi. Langkah ini sangat perlu dilakukan oleh guru agar siswa termotivasi untuk belajar.

Dalam pengembangan media pembelajaran harus sesuai kondisi siswa dan sekolah. Untuk itu perlu dilakukan analisis kebutuhan. Adapun hasil pengamatan penulis, menunjukkan bahwa pembelajaran tematik akan efektif apabila siswa aktif dalam pembelajaran. Dengan pendekatan STEAM, ternyata mendorong siswa mampu berpikir aktif dan kreatif, sehingga siswa senang belajar. 


\section{Desain/Merancang Media Pembelajaran}

Dari analisis kebutuhan diperoleh informasi, ternyata siswa sangat senang apabila pembelajaran dengan pendekatan STEAM. Pendekatan ini ternyata sangat efektif untuk mendorong siswa untuk berkipir kritis dan kreatif. Adapun media yang cocok untuk pembelajaran tematik 1 di SD dengan pendekatan permainan yang terintegrasi dengan kompetensi. Permainan yang mudah dikenali oleh siswa SD kelas 1 yaitu warna. Ternyata anak SD kelas 1 ketika diperkenalkan warna mereka antusias dan ketika diminta menyebutkan warna itu mereka senang dan menginspiratif. Berdasarkan hal itulah dibuat media permainan warna yang disebut Media Tak Tik Butarna

\section{Pengembangan Media}

Media Tak Tik Butarna merupakan media inovasi pembelajaran hasil kreativitas guru kelas tematik, dimana media Tak Tik Butarna merupakan akronim dari media otak atik bangun datar warna. Media Tak Tik Butarna dalam implementasinya dapat digunakan di semua tema yang ada di kelas 1. Unsur - Unsur yang di otak atik dalam materi ini adalah muatan pelajaran yang ada pada setiap tema, baik muatan pelajaran PPKN, Bahasa Indonesia, Matematika, serta SBDP. Kesimpulannya media Tak Tik Butarna dapat diimplementasi di semua tema yang ada di kelas tematik. Produk media dapat dilihat pada gambar 1, gambar 2, dan gambar 3.

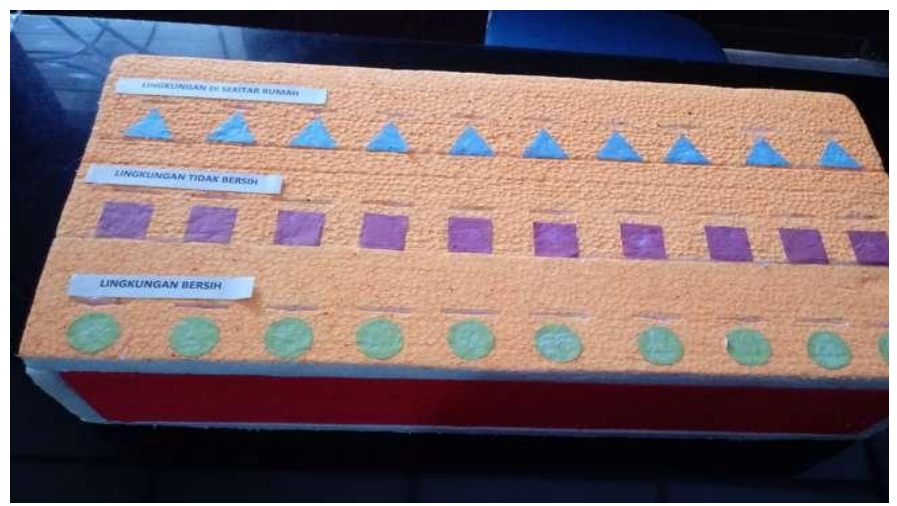

Gambar 1. Balok Tak Tik Butarna (Otak Atik Bangun Datar Warna) 


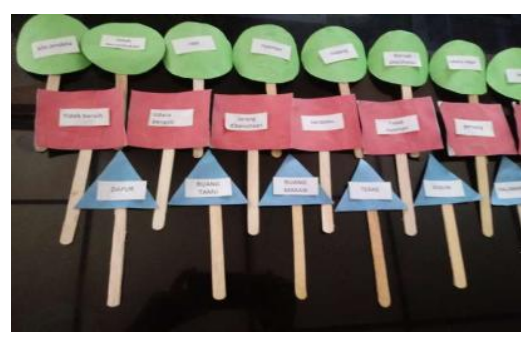

Gambar 2. Stik Tak Tik Butarna (Otak Atik Bangun Datar Warna)

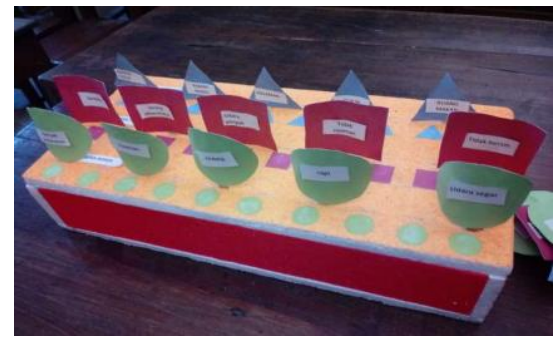

Gambar 3. Media Tak Tik Butarna Berbasis STEAM

Media Tak Tik Butarna berbasis STEAM bertujuan untuk memberikan kemudahan belajar kepada peserta didik dalam mempelajari muatan pelajaran yang ada pada setiap tema. Media Tak Tik Butarna bertujuan agar peserta didik dengan mudah mengenal pengetahuan tentang sains, teknologi, teknik, seni, dan matematika. Dalam penerapannya, media Tak Tik Butarna dapat digunakan dalam semua tema yang ada di kelas. Dalam kegiatan pembelajaran, hal yang di otak atik dengan menggunakan media Tak Tik Butarna adalah muatan-muatan pelajaran yang ada pada setiap tema. Berikut ini visualisasi hubungan STEAM dengan Media Tak Tik Butarna dalam pembelajaran di kelas tematik.

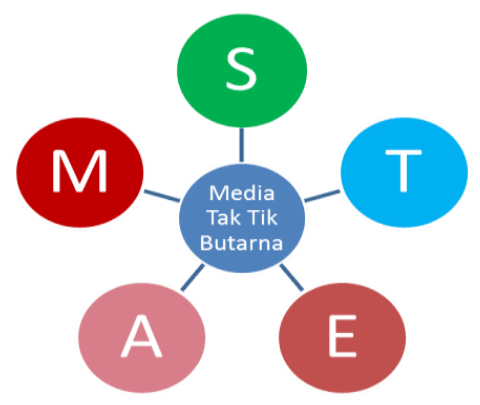

Gambar 4. Hubungan STEAM dengan Media Tak Tik Butarna 
Sains, unsur sains yang menghubungkan dengan media Tak Tik Butarna adalah muatan - muatan pelajaran sains yang di otak atik dengan menggunakan media Tak Tik Butarna. Peserta didik dengan mudah menangkap pengetahuan sains yang ada pada setiap muatan pelajaran.

Technology, unsur teknologi yang menghubungkan dengan media Tak Tik Butarna adalah keunikan dari media Tak Tik Butarna sebagai inovasi media pembelajaran karya guru sendiri yang disesuaikan dengan kondisi peserta didik.

Engineering, unsur teknik yang menghubungkan media Tak Tik Butarna yaitu strategi atau model pembelajaran yang digunakan dalam pembelajaran saat implementasi media Tak Tik Butarna, yang pada akhirnya dapat memberikan atmosfir kelas yang kondusif.

Art, unsur seni yang menghubungkan media Tak Tik Butarna antara lain, peserta didik mengenal permainan saat menggunakan media Tak Tik Butarna sehingga dapat meningkatkan keaktifan peserta didik.

Mathematics, unsur matematika yang menghubungkan media Tak Tik Butarna di antaranya, dengan menggunakan media Tak Tik Butarna, peserta didik mendapatkan pengalaman belajar mengenal geometri bangun datar sederhana, seperti persegi, segitiga, lingkaran serta keterampilan berhitung mengenal bilangan.

Media Tak Tik Butarna berbasis STEAM merupakan alat bantu dalam kegiatan belajar untuk meningkatkan aktivitas peserta didik, dalam kajian ini untuk meningkatkan literasi sains dan pada akhirnya berdampak pada keterampilan berpikir kritis peserta didik pula. Literasi sains diperkenalkan kepada peserta didik dengan memberdayakan media Tak Tik Butarna berbasis STEAM. Literasi sains dikembangkan dalam kegiatan pembelajaran tematik dengan cara mengaitkan tema lingkungan bersih sehat dan asri. Penggunaan media Tak Tik Butarna berbasis STEAM pada tema lingkungan bersih sehat dan asri berorientasi pada peningkatan keterampilan berpikir kritis peserta didik, keterampilan berpikir kritis disini pada akhirnya tidak hanya pada pembelajaran penggunaan media Tak Tik Butarna berbasis STEAM saja namun diharapkan juga pada 
pembelajaran pada tema-tema yang lain. Hubungan antara media Tak Tik Butarna dengan kemampuan berpikir kritis dan literasi sains ini divisualisasikan pada gambar berikut.

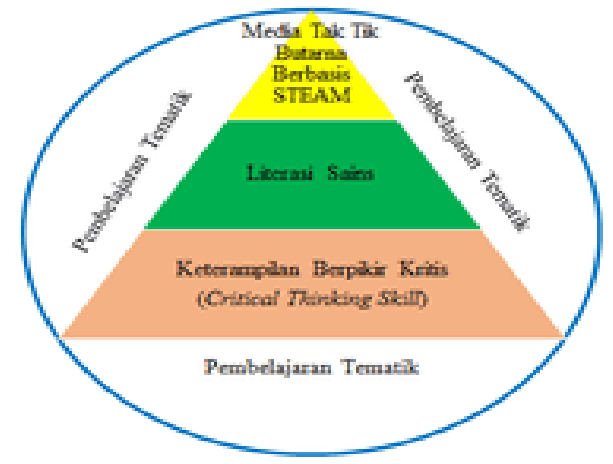

Gambar 5. Hubungan Media Tak Tik Butarna dengan Keterampilan Berpikir Kritis dan Literasi Sains

\section{Implementasi/Penerapan dalam Pembelajaran di Kelas}

Tahapan dalam pembelajaran di kelas dapat dilakukan oleh guru sebagai berikut:

1. Menyusun RPP dengan memasukkan media Tak Tik Butarna sebagai media pembelajaran.

RPP merupakan janji guru kepada para pemangku pendidikan di sekolah yaitu siswa, kepala sekolah, pengawas, pemerintah, dan masyarakat dalam kegiatan pembelajaran. dengan RPP ini guru berjani akan melakukan pembelajaran di kelas sesuai yang sudah direncakan. Untuk itu dalam menyusun RPP guru harus menyadari betul bahwa itu janjinya terutama kepada siswa. Apabila dalam menyusun RPP diniatkan dengan hati yang tulus karena sesuai sumpah dan janji sebagai guru, maka akan menjadi catatan dalam kehidupannya. Untuk itu setiap pembelajaran harus berkesan bagi siswa dan gurunya.

\section{Melakukan pembelajaran}

Penggunaan media Tak Tik Butarna berbasis STEAM dalam pembelajaran tematik diterapkan guru melalui permainan talking stick. 
Tahapan-tahapan aplikasi Tak Tik Butarna berbasis STEAM dalam kegiatan pembelajaran tematik mengikuti tahapan berikut.

Tahap menganalisis, guru memberikan penjelasan tentang pengenalan media tak tik butarna berbasis STEAM kepada peserta didik dan manfaat media dalam pembelajaran. Guru memberi orientasi serta motivasi cara mendemonstrasikan media tak tik butarna berbasis STEAM dan cara menggunakannya.

Tahap mensintesis, merupakan inti dari implementasi media tak tik butarana berbasis STEAM dalam integrasi bersama pembelajaran tematik serta membangun keterampilan berpikir kritis peserta didik. Peserta didik dibawah bimbingan guru mencoba menggunakan media yang sebelumnya melalui permainan talking stick. Peserta didik diminta maju ke depan untuk menyebutkan jenis stick bangun datar berlabel kata kunci tema lingkungan bersih sehat dan asri kemudian menjodohkannya di bangun datar yang ditempel pada kotak tak tik butarna. Setelah itu peserta didik mengambil lagi stick bangun datar yang berbeda untuk disampaikan kepada peserta didik lain melalui permainan talking stick.

Begitu seterusnya permainan ini dilakukan sampai stick-stick bangun datar yang ada tertancap pada bangun datar yang sesuai jenisnya yang terdapat pada balok tak tik butarna.

Tahap membuat kesimpulan, peserta didik ditugaskan untuk menceritakan kembali secara lisan jenis-jenis bangun datar yang sudah dipelajari serta mengaitkannya dengan literasi sains tema lingkungan sehat bersih dan asri.

Tahap mengatur strategi dan taktik, peserta didik diminta untuk menggambar bangun datar sederhana persegi, segitiga dan lingkaran di lembar buku masing-masing.

\section{Hasil Pengukuran Keterampilan Berpikir Kritis dan Literasi Sains}

Hasil aplikasi praktis inovasi pembelajaran pada pengembangan media tak tik butarna berbasis STEAM pada pembelajaran tematik menunjukkan bahwa dengan pengembangan media tak tik butarna berbasis STEAM, 
memberikan peningkatan terhadap literasi sains dan keterampilan berpikir kritis peserta didik.

Berdasarkan hasil penelitian sebelum menggunakan media tak tik butarna berbasis STEAM diketahui rata-rata kelas keterampilan berpikir kritis peserta didik 74,80 dan rata-rata kelas literasi sains 73,61. Berdasarkan hasil penelitian sesudah menggunakan media tak tik butarna berbasis STEAM dapat diketahui bahwa rata-rata kelas keterampilan berpikir kritis peserta didik 86,67 dan rata-rata kelas literasi sains 88,67. Dari hasil penelitian sebelum dan sesudah menggunakan media tak tik butarna berbasis STEAM dapat disimpulkan bahwa media tak tik butarna berbasis STEAM dapat meningkatkan keterampilan berpikir kritis peserta didik dan literasi sains dalam pembelajaran di kelas.

Penggunaan media yang tepat dapat meningkatkan aktivitas siswa dalam kegiatan pembelajaran, termasuk aktivitas pemecahan masalah sehingga merangsang siswa untuk berpikir kritis (Syawaludin et al., 2019; Feuerstein, 2015). Melalui penggunaan media Tak Tik Butarna, guru dapat membangun kemampuan peserta didik dalam memecahkan masalah yang ada di kelas, membantu keaktifan peserta didik dalam merangsang kemampuan berpikir kritis serta peserta didik lebih mudah menemukan, memahami konsep-konsep yang sulit.

Penggunaan media Tak Tik Butarna mengikuti sintaks pembelajaran STEAM. Penerapan pendekatan STEAM dalam penggunaan media pembelajaran ini terbukti mampu meningkatkan kemampuan siswa dalam memecahkan masalah (Kim \& Choi, 2012). Kemampuan pemecahan masalah yang meningkat diikuti dengan pengembangan literasi sains, dimana siswa dengan mengikuti pendekatan STEAM mampu menemukan jawaban atas permasalahan secara ilmiah (Long et al., 2017; Land, 2013).

Proses pembelajaran terpusat pada peserta didik sehingga dapat melibatkan keaktifan siswa pembelajaran di dalam kelas. Guru memberikan suatu permasalahan dalam pembelajaran dapat menciptakan suasana belajar yang lebih baik di mana suatu permasalahan tersebut dapat memacu peserta 
didik memperoleh jawaban suatu permasalahan maupun cara penyelesaian masalah secara beragam. Hal ini sejalan dengan teori belajar Vyotsky, menyatakan bahwa terjadinya interaksi sosial dengan teman lainnya sehingga memicu terbentuknya ide-ide gagasan yang baru serta memperkaya perkembangan intelektual peserta didik.

\section{Evaluasi}

Setelah diimplementasikan media tersebut dalam pembelajaran, hasilnya ternyata media Tak Tik Butarna sangat efektif untuk meningkatkan daya serap, berpikir kritis, dan kreatifitas siswa. Hasil evaluasi menunjukkan bahwa media ini perlu dilakukan penyesuaian apabila akan diterapkan di kelas. Hal ini dikarenakan setiap kelas atau setiap sekolah memiliki lingkungan yang dan kondisi yang berbeda. Dengan demikian media ini perlu terus dialukan penyesuaian setiap tahun dan setiap tempat.

\section{Penutup}

\section{Kesimpulan}

Dari hasil dan pembahasan dapat disimpulkan sebagai berikut:

a. Media Tak Tik Butarna berbasis STEAM pada pembelajaran tematik untuk meningkatkan keterampilan berpikir kritis dan literasi sains pada peserta didik kelas I merupakan salah satu inovasi pembelajaran guru yang disusun sebagai media belajar yang pada akhirnya memberikan optimalisasi dan peningkatan hasil belajar peserta didik.

b. Media Tak Tik Butarna berbasis STEAM dalam penerapannya memberikan dapat positif terhadap keterampilan berpikir kritis dan literasi sains peserta didik, hal ini ditunjukkan dengan peningkatan keterampilan berpikir kritis peserta didik yang sebelumnya ratarata 74,80 meningkat menjadi 86,67 . Peningkatan literasi sains yang sebelumnya rata-rata 73,61 meningkat menjadi 88,67.

\section{Saran}

a. Setiap guru ketika akan mengajar harus berpikir bagaimana agar pembelajaran saat itu berkesan bagi siswa dan guru. Agar 
berkesan, maka perlu memanfaatkan media baik buatan sendiri atau media yang sudah ada.

b. Dalam pengembangan media, guru harus menyesuaikan dengan kebutuhan siswa dan kondisi sekolah agar dalam pelaksanaannya efektif.

\section{Ucapan Terimakasih}

Peneliti mengucapkan terimakasih yang sebesar-besarnya kepada keluarga besar SD Negeri Laweyan Kota Surakarta yang telah memfasilitasi dalam keterlaksanaan penelitian ini dan tak lupa pula kami ucapakan terima kasih kepada Kesharlindung Kemdikbud yang telah memfasilitasi dalam publikasi hasil penelitian ini.

\section{Daftar Referensi}

Aldila, C. (2017). Pengembangan LKPD Berbasis STEM untuk Menumbuhkan Keterampilan Berpikir Kreatif Siswa. Jurnal Pendidikan Fisika, 5, 85-95

Apriliana, dkk. (2018). Pengembangan Soft Skills Peserta Didik Melalui Integrasi Pendekatan Science, Technology, Engineering, Artss, And Matematics (STEAM) dalam Pembelajaran Asam Basa. Jurnal Riset Pendidikan Kimia, 8 (2)

Falahudin, I. (2014), Pemanfaatan Media Dalam Pembelajaran, Jurnal Lingkar Widyaiswara Edisi 1 No. 4, Oktober-Desember 2014, 104-117

Feuerstein, M. (1999). Media Literacy in Support of Critical Thinking. Jornal of Educational Media, 24(1), 43-54

Gantari, R. (2016). Pembelajaran Membaca Dengan Pendekatan Proses Untuk meningkatkan Budaya Literasi Siswa di Sekolah Dasar. Jurnal Ilmiah Guru "COPE", No. 02/Tahun XX/November 2016

Gherardini, M. (2016). Pengaruh Metode Pembelajaran Dan Kemampuan Berpikir Kritis Terhadap Kemampuan Literasi Sains. Jurnal Pendidikan Dasar, 7 (2)

Haryanto, MAK. (2017). Pengembangan Media Peraga Untuk Pembelajaran Kompetensi Mengidentifikasi Final Drive Penggerrak Roda Belakang. Jurnal Pendidikan Teknik Mesin, 17 (1), 25-31 
Permanasari, A. (2016). STEM Education : Inovasi dalam Pembelajaran Sains. Seminar Nasional Pendidikan Sains "Peningkatan Kualitas Pembelajaran Sains dan Kompetensi Guru Melalui Penelitian \& Pengembangan dalam Menghadapi Tantangan Abad 21", Surakarta, 22 Oktober 2016

Imaduddin, M. (2017). Mendesain Ulang Pembelajaran Sains Anak usia Dini Yang Konstruktif Melalui STEAM Project Based Learning Yang Bernuansa Islami, Prosiding Annual Conference For Muslim Scholars 2017 halaman 950-958, 13-14 Mei 2017

Irawan, A. (2016). Penerapan Strategi pembelajaran Kontekstual Untuk Meningkatkan Kemampuan Berpikir Kritis Matematika. Jurnal Ilmu Pendidikan, 22(1), 9-17

Kim, G.-S., \& Choi, S. Y. (2012). The effects of the creative problem solving ability and scientific attitude through the science-based STEAM program in the elementary gifted students. Journal of Korean Elementary Science Education, 31(2), 216-226

Land, M. H. (2013). Full STEAM ahead: The benefits of integrating the arts into STEM. Procedia Computer Science, 20, 547-552

Lestari, A. (2017). Pengembangan Soal Tes Berbasis HOTS Pada Model Pembelajaran Latihan Penelitian Di Sekolah Dasar. Jurnal Ilmu Pendidikan, 22(1), 9 - 17

Long, Robert L. II and Davis, Stephen S. (2017). Using STEAM to Increase Engagement and Literacy Across Disciplines. TheSTEAM Journal, 3(1). DOI: 10.5642/steam.20170301.07

Mulyatiningsih, Endang (2012). Metode Penelitian Terapan Bidang pendidikan. Alfabeta : Bandung

Primasari, R dkk. (2014). Penggunaan Media Pembelajaran Di Madrasah Aliah Negeri Se- Jakarta Selatan, EDUSAINS, 1, 68 - 72

Syawaludin, A., Gunarhadi, \& Rintayati, P.(2019). Development of Augmented Reality-Based Interactive Multimedia to Improve Critical Thinking Skills in Science Learning. International Journal of Instruction, 12(4), 331344. https:// doi.org/10.29333/iji.2019.12421a

Wulandari, dkk (2016). Analisis Kemampuan Literasi Sains Pada Aspek Pengetahuan Dan Kompetensi Sains Siswa SMP Pada Materi Kalor, EDUSAINS, Volume Nomor 08 Tahun 2016, halaman 66-7 
Vol. 4, No. 3, November 2020 